\title{
International Human Resource Management in an Era of Political Nationalism
}

Please cite as

Horak, S., Farndale, E, Brannen, M.Y. and Collings, D.G. (2018) International Human Resource Management in an Era of Political Nationalism, Thunderbird International Business Review , doi 10.1002/tie.21959

Sven Horak, Ph.D.*

Assistant Professor of Management

The Peter J. Tobin College of Business

Department of Management

St. John's University

8000 Utopia Parkway, New York 11439, USA

Phone: +1 718-990-7310, Email: horaks@stjohns.edu

Elaine Farndale, Ph.D.

Associate Professor of Human Resource Management

School of Labor and Employment Relations

Center for International Human Resource Studies (CIHRS)

The Pennsylvania State University

501c Keller Building, University Park, PA 16802, USA

Phone: +1 814-867-3320, Email: euf3@psu.edu

Mary Yoko Brannen, Ph.D.

Dr. Merc. H. C. Copenhagen Business School

Professor and Jarislowsky CAPI East Asia (Japan) Chair

Centre for Asia-Pacific Initiatives (CAPI)

University of Victoria

Sedgewick Building, room C128

PO Box 1700 STN CSC

Victoria BC V8W 2Y2, Canada

Phone: +1 250-721-7020, Email: maryyoko@uvic.ca

David G. Collings, Ph.D.

Professor of Human Resource Management

Leadership \& Talent Institute

Dublin City University Business School

DCU Glasnevin Campus

Glasnevin, Dublin 9, Ireland

Phone: +353 1700 6937, Email: david.collings@dcu.ie 
* Corresponding author 


\section{International Human Resource Management in an Era of Political Nationalism}

\section{Executive Summary}

In times of the "Brexit" and "America First" policies, several industrialized countries' governments are turning towards more national-oriented migration policies. Simultaneously, societal aversion to immigration is growing. Both trends are sending negative signals to highly skilled employees and making immigrants feel that they are no longer welcome. Consequently, international careers are becoming uncertain, risky, and unpredictable. This new reality in industrialized knowledge-based economies may affect firms' talent pool and the skill set available to a country. To shed light on the new environment of international human resource management, we interviewed Mary Yoko Brannen and David Collings, leading experts in the field, to explore their perspective on how the field is changing. The interviews reported here uncover fascinating insights, including the need to counteract the globalization fears in the West of the predominantly white working and lower-middle class through education. Companies may also rethink their organizational boundaries and the notion of traditional employees by using their agility to counteract the political forces harming their talent pool strategy.

\section{Keywords}

International HRM, global talent management, nationalism, migration, hidden talent, skill sets 


\section{Introduction}

Though the advantages of globalization have been assumed to outweigh the challenges, today anti-globalization sentiments appear to be developing increasingly into mainstream opinion. Especially countries that have actually pushed and for a long time benefitted from globalization are now surprisingly turning more towards isolationist and nationalistic policies. Recent and meaningful examples include "Brexit," that is, Great Britain leaving the European Union, in which a substantial desire was to regain control over immigration policies (Reuters, 2016). In the United States, Donald J. Trump was elected president after explicitly advocating a nationalistic policy under his "America First” slogan. He has so far tried multiple times to ban immigrants and refugees from (re-)entering the United States by executive order, though legal challenges have been raised (Burns, 2017). These measures have caused harsh complaints from several US firms, among others Apple, Google, Tesla, Uber, and Facebook, which filed an amicus brief in the United States Courts of Appeals (Streitfeld, 2017). It is especially these high-tech firms that are experiencing difficulties: key employees in regions such as the Silicon Valley are facing problems re-entering the country while on business trips; and newly hired talent is experiencing difficulties receiving work visas.

While the events in the United States and Great Britain dominate the media, more voters in several European countries are tending to follow political leaders who stress the national identity and plan to restrict immigration. In France, the right-wing party Front National (FN) has meanwhile developed a strong political force in the country. In the Dutch general election of 2017, Geert Wilders's far-right party Partij voor de Vrijheid (PVV, Engl.: Party for Freedom) became the second-strongest political force in the Netherlands, and Viktor Orbán, Prime Minister of Hungary, is well known for his eurosceptic views and national conservatism. The gains by the 
far right party in Germany, the Alternative for Germany, in winning almost $13 \%$ of the vote in the September 2017 elections further reinforce these examples. As these trends are taking place in some of the largest economies in the world that have formerly embraced immigration and benefitted from globalization, they are remarkable. Globalization has caused controversial debates in the past (Osland, 2003; Peng \& Shin, 2008), but ultimately freer trade has generally been assumed to increase the wealth of a nation and its people (Dollar \& Kraay, 2002). Open labor markets have been regarded positively in terms of their economic benefits and perceived as being particularly advantageous for aging societies (Dustmann, Frattini, \& Halls, 2010).

As shown by Silicon Valley firms' engagement of panic mode in response to the travel ban in the United States, nationalistic policies and immigration bans can be regarded as a threat to international human resource management (IHRM), since they show the extent of the impact that changes in the macro environment can exert on IHRM (Cooke, 2014). From an IHRM point of view, this new situation poses interesting questions that have so far played a rather secondary role in the field (Frith, 2016). First and foremost, a pressing issue is how to rationalize the current situation. What does the current trend of political isolationism and societal antiimmigrant sentiment in several industrialized countries mean for IHRM and global talent management? What are the potential consequences for the talent pool structure and HR architecture of a firm? Do firms have to adjust their HR architecture? Will firms headquartered in such countries lose the "war for talent" in the long run? What can organizations do to counteract the negative influences on their IHRM policy if they are headquartered in countries that adopt anti-immigration policies?

Two experts in the field of interest are Mary Yoko Brannen (University of Victoria, Canada), a noted Organizational Anthropologist, and David Collings, a distinguished 
International Human Resource Management scholar (Dublin City University, Ireland). In the following interviews, we first talk to Mary Yoko Brannen, with whom we discuss and identify the causes of the resistance to immigration and the unique and valuable skill sets that people with a multicultural background bring to organizations in the context of the recent nationalist tendencies in the US and several European countries. Building on that, we subsequently interview David Collings about the particular challenges and consequences of political isolationism for a global talent management strategy. Brief biographies of Mary Yoko Brannen and Dave Collings can be found at the end of the article.

\title{
Edited transcript
}

\section{Rationalizing globalization fears and the role of the new demography Mary Yoko Brannen [MYB]}

\begin{abstract}
As we see several countries turning towards more isolationistic policies, how do you feel about this as a scholar focusing on multinational affairs in a business context?
\end{abstract}

MYB: I think there is a real split among the population of many countries. It's more like a schism, and I think it's one that can be rectified. I believe that international business scholars and practitioners have a big role to play here. To me, it appears that we've failed to help our constituencies understand the world — its societies and economies — and especially the nature and effects of globalization. Taking a look at the recent political trends in several countries and in particular the election results in the UK and the USA, what they say to me is "fear". It's fear of 
globalization and it is economic for the most part, but it is also a very basic fear of the Other people who look, think, and act differently from ourselves — a fear which has been around from the beginning of time. So I think, especially as academics and educators, we need to help with the root cause of this issue of isolationism, and the root cause is fear. I think it's this kind of fear that IB scholars and practitioners - especially those in cross-cultural management and HR — can help to assuage.

The other big issue that has led to this nationalism turn in both the USA and the UK, is that we've neglected the middle-class and especially low-income households. The middle class has shrunk in these two countries leaving a growing working class with individuals who feel their jobs are endangered because of globalization and migration. As IHR scholars, we need to increase the awareness of the nature of globalization-its economic reality (not one-sidedly negative) and the nature of immigrants (who they are, why they immigrate, what skills they bring).

Since globalization also creates opportunities, how can this "new" fear of globalization be explained? Is it actually new?

MYB: To a great extent, it is the fear of losing jobs - and, this too is a fear that has been around for a long time. However, there is a big difference between migration mobility and immigration, now and in the past, in particular in regard to the volume, direction and location of migration. According to UN statistics, the past two decades has witnessed a 250 times growth in migration worldwide. Rather than migration taking place in a unidirectional fashion as in the past from East to West, it has now become decidedly multidirectional—East-West, West-East, North-South and 
South-North, and it is not static but dynamic — with immigrants regularly returning to their countries of origin actively nurturing important social and organizational networks. Further, migrants are localizing predominantly in urban areas, and even though nation states depend on organizations to integrate these migrants into the workforce, the issue of immigration and integration in organizations hasn't figured largely in the management discipline. There is a massive disconnect between public policies and organizational realities. International HR academics and practitioners, then, need to be addressing this reality. How can we help the incumbent employees not to feel threatened by immigrants? How can we help them not to be afraid of losing their jobs? How can we help organizations appreciate this tidal wave of migration, and even begin to recognize and appreciate the diverse skill sets they bring? These are things we need to think about.

In addition, there are widely held beliefs about migrants that need to be corrected. To point, it is generally assumed that migrants predominantly come from low-income backgrounds, are generally low-skilled and are thereby a drain on host country resources. Rather, the World Migration Report statistics show that the stock of highly skilled immigrants migrating from middle-income nations is readily increasing. In fact, if we considered the 244 million international migrants living abroad in 2016 as a country, (named something like "Migrantia"), this country would constitute the fifth-largest economy in the world. These migrants straddling host and home countries-of-origin are in fact responsible for over 400 billion dollars remitted annually into the economy. So, "Migrantia" is actually an economically remarkable group of people. As IHR scholars, we should create more awareness about this and help people in the workplace understand this changing demographic and the role it plays in the world economy. Nonetheless, the fear of the threat to job security remains strong especially among mid-to 
low-income wage earners. And, this is not new. I remember back when I was doing my dissertation, when Japanese companies were taking over companies all over the United States, there was a huge resistance. There was the movie Gung-Ho, a caricature of Japanese management domination over American work life. People were very, very worried that their jobs, whether they be in textiles, athletic shoes, or auto manufacturing, would be lost to lower wage-rate countries in Asia. In my dissertation, even though it was a Japanese firm, that acquired a Western Massachusetts paper mill that I chose to study, it didn't matter if it was Japanese or not - the incumbent employees just equated Japanese with all Asians and feared for their livelihood. This, in their eyes was the meaning of globalization.

\section{Did this development result in more nationalistic policies in those years?}

MYB: Very much so. There were trade embargoes, resistance, lots of anti-Japanese sentiments in the popular press. The Japanese companies at the time had to do a lot, a whole lot, of preparing against this resistance so that people would accept them, and keep an open mind. Many Japanese companies bought factories that were owned by holding companies that hadn't had money put into them for long periods of time. So when the factory workers in the takeover that I studied saw that the new Japanese management was there to stay and that they were going to put money into equipment, they were speaking a language the factory workers could understand and this helped to assuage some of the fears. As international business academics, I feel we shoulder a certain failure in not having educated people well enough in regard to what globalization is about, and also I feel like there's a real role especially for international HR to play in terms of educating and training. 
Following this example, international businesses appear to have done their job. Has the political arena failed to communicate the opportunities and challenges of globalization?

MYB: Absolutely! It was not the foreign companies that didn't do their job; they did do their job. They increased the economic environment and the visibility and viability of regions. I think the real problem is that the politicians didn't pay enough attention to the sentiments and living environments of the working class. When thinking about the political trends in the UK and the USA, some politicians set their priorities on themes that appeared to have no urgent priority for the working class and that was and still is a real problem. Leading up to the elections in the UK and the USA, there was a marked lack of discussion in regard to the diminishing middle class and increasingly difficult economic condition of the working class in these countries.

So where do we fit in as academics? I think if we could educate people more in terms of globalization, how globalization works and that it happens in all countries; for example, that the life expectancy of industries, as economies grow, will diminish and they will go on to other countries as new industries will crop up at home. Just understanding such things as this will help, and how HRM can help to retrain individuals in different industries. I think there is a big role to play for international HR — to help educate and retrain—especially for working class people.

Compared with the USA, Canada seems to perform better in this regard. Is Canada more successful in taking away the fears of the people through its multiculturalist approach compared with the US melting pot approach? 
MYB: I think it depends on your perspective. If you were asking Quebecois people what the Canadians felt about what Canadian policy makers term the "cultural mosaic" - the outcome of their multiculturalism policy — they would say that they don't feel that they're really able to maintain their distinct culture and there's clearly a resistance against what they see as a hegemony of the "English". Recent research that we are conducting at the University of Victoria using Canadian workplace employment data reveal that despite its laudable intent, Canada's multiculturalism policy is not a perfect system especially at the organizational level. We're finding, not surprisingly, that there's a privileging of the invisible minority — the immigrants who are able to blend in both culturally and linguistically. It seems even in Canada assimilation is rewarded. What we are finding is that immigrants who can assimilate more easily, those who don't look any different from monocultural Canadians and who speak English at home, are the ones who are enjoying better workplace outcomes including higher wages, promotion, and supervisory power. So that's kind of sad to see, because it reveals that you can have a policy in place, but still have biases in terms of HRM on the ground. This is unfortunate, but expected given that much of the skillsets that biculturals bring to the workplace-for example, perceptual acuity, cognitive complexity, conflict management skills - are tacit in nature and neither the employers nor the individuals themselves are aware of what they bring.

To me it appears that in a globalized world biculturals have a competitive advantage in the job market over the monocultural working class, since people who understand different cultural contexts better may be more sensitive to interpersonal challenges and it may be easier for them to overcome the barriers. 
MYB: You have to be careful here, because the working class is certainly not always monocultural. For example, in my dissertation work, at a factory in Western Massachusetts where I spent two and a half full years of study - I was shocked to realize that the workers I assumed were monocultural Western-Massachusett Americans, were actually bicultural themselves. I found this out when I went to triangulate my findings by giving a sit-down census. A couple of the factory workers asked if they could take the census home, and I thought, "why would they want to do that?' It turned out they were illiterate, because they were PolishAmerican and spoke Polish at home and couldn't read English well. They wanted their relatives to do the survey with them. In addition, there were many French-Canadians in the workforce who spoke English as a second language. This realization brought a whole new understanding of the context of my dissertation and the nature and scope of biculturalism at the plant. Thinking that it was mainly a binary "us (Americans) versus them (Japanese)" issue, I assumed that the bicultural alienation I was seeing was an organizational level phenomenon. But, then I started going back over my findings, and, began to see that at there was a lot of variance in such alienation at the individual level. Whereas monocultural middle managers especially in functional roles directly impacted upon by the takeover (such as production, engineering and finance) felt quite a bit of work alienation from the new Japanese management, the workingclass Polish-Americans and French-Canadian-Americans did not. They were the ones that were flexible and open to changes being made and especially tolerant of Japanese being spoken in sidebars. They understood the necessity of speaking in one's own tongue for expediency, because they themselves grew up in families where their parents would do much the same. Working-class people have other types of cultural intelligence that matter; when they work hand-in-hand with someone, they value actions above words and readily go to bat for those 
who step up to the plate. So it's a different type of intelligence, than that of highly skilled immigrants. We need to be careful here not to generalize.

Seeing this challenge, I keep putting my HR hat on and just thinking of the challenge that faces the HR people in an organization, who are probably monocultural themselves, trying to manage their way through it. They probably don't understand the best way to tap into this resource or what this resource could potentially create for the organization.

MYB: Well, monoculturals can potentially be blind to certain situations and actions that require mediation, whereas biculturals often can rely on their dual-knowledge bases to create bridges. This kind of boundary spanning capability will become more and more valuable in the future as the world continues to globalize. If you look at the statistics of North America today, the number one demographic entering the workforce today is multicultural. It's this group of people who are very aware of different ways of thinking and acting. Rather than monochromatic petals on a flower, these individuals are intrinsically multicolored hybrids and as such, they can utilize their intrinsic nature to become important bridges—both organizationally and interpersonally. What is important is for us as HR and cross-cultural scholars is that we stop depicting the workforce as static and monolithic cultural "billiard balls", as it were. This is divisive. We need to quit relying on models of aggregate cultural values to explain differences, and open our eyes to the reality of today's organizational workplace. I hate saying this over and over again, but aggregate cultural norms are not really helpful in the daily and highly context-specific work routine in companies. 


\section{How can the skills that the new demographic has be assessed? What could they look like from}

an academic and practitioner point of view?

MYB: Well, a lot of social psychologists have come up with instruments to measure biculturalism. For instance, the BII, the bicultural identity integration instrument, can be useful, but that's not as finely tuned as one would hope. So there are a lot of opportunities for scholars to advance this field in the future. If you're a practitioner, then you'd simply speak to your employees and get to know them individually rather than by making assumptions about their cultural identity based on aggregate cultural data.

What I tend to do is to talk about variance. Just as there is a great deal of variance within cultures, there is much variance among biculturals, I talk about neither/nor biculturals-who don't feel like they really are accepted in the country in which they reside nor in their country of origin. These biculturals are distinct from those I call "one home" biculturals. Like an IndianAmerican who has never been to India and doesn't speak an Indian language but knows a lot about India socially through his or her parents and would identify more as an American first and foremost. And then there are "both-and" biculturals who are distinct from "either-or" biculturals. How are they different and what can they bring to the organization? The neither-nor bicultural versus the global cosmopolitan for instance has a very different skill set that he or she brings to organizations. The global cosmopolitan is one who is less neurotic and much more adaptive and resilient. Think about an engineer who's a global cosmopolitan, so someone who's focused and doesn't see the cacophony of cultural differences. That's a certain kind of person that you can send anywhere for a few days to solve a problem. On the other hand, if you want a very conceptual, very reflective, person who can see differences that matter and step in to solve 
cultural clashes before they get out of hand, you would choose a neither/nor bicultural. They both just have very different skill sets. So what I would recommend practitioners to do is to start talking about and considering these characteristics of the new workplace demographic. This could be a part of a global leadership competencies program of a firm, to understand these nuances and be able to see these skillset in their employees and leverage them for their organization.

Do you see a risk that nationalistic policies can restrict companies from tapping into these valuable skill sets that people bring?

MYB: The good news is that, no matter what happens at the policy level of the nation states, we already have these people who are the new demographic. HR has got to start figuring out how to recognize the skills that they bring. Whatever political leaders do, they're already here. They're not going to be kicked out, especially the second- and third-generation individuals. We're not recognizing the skills that they bring yet, and we need to do that.

\section{Nationalistic policies and global talent management Dave Collings [DC]}

As we currently see in the political arena a trend of reducing immigration rather than increasing it in many European countries, such as the UK pursing Brexit, HR strategies may be affected. What do you think this situation means for global talent management in particular? 
DC: The first thing that comes into my mind is uncertainty. I think there are a lot of unknowns right now in terms of where this will go. Brexit is a good example. Nobody knows how the negotiations will go with the EU and what kind of Brexit we'll have, whether it'll be a soft Brexit or a hard Brexit, but in the context of global talent management, any source we have suggests that there are shortages of skilled labor in key developed markets around the world. That is partly a result of aging and demographic changes and partly a result of the quality and quantity of people in STEM (science, technology, engineering, and math) professions, etcetera. Most developed economies rely on significant numbers of skilled and indeed unskilled migrants to fill the gaps in the labor market that are evident. As for the UK, forecasts assume that onehundred thousand migrants are required per annum simply to meet the talent requirements. I think the number of $\mathrm{H}-1 \mathrm{~B}$ visas in the United States is around sixty-five thousand per annum, which seems relatively small in the scheme of things, but nonetheless that's currently the status.

So if the context is that organizations can't meet their skills needs with indigenous domestic labor markets, then I think there's absolutely a requirement for skills. The political narrative in the UK and the US and other economies certainly threatens the people's willingness to move to those economies. It certainly makes organizations reevaluate where they're going to base their operations. In the European context, the context of Brexit, we see a lot of financial institutions looking at the likes of Frankfurt, at Dublin and at other European capitals in order to relocate some of their facilities to ensure they have a base in the European Union market. Also, from a skills perspective, firms want to make sure that they can access the talent they want and need. So, I think the boundaries are shifting; the boundaries are very uncertain and I think it could have an impact on that. 
While MNCs are quite flexible in moving across borders, is the labor market really that mobile to follow? Do you see challenges to employee mobility?

DC: The reality is that technical talent clusters in areas. We know Silicon Valley and we know Boston or Massachusetts more generally, we know there are areas where it clusters and you can't simply move to a new area and create those ecosystems. So there are certain places that have advantages over others in terms of where organizations can potentially locate. Going back to an organizational point of view, I think you're absolutely right, I think organizations have the advantage of being mobile. I think organizations need to think about the potential scenarios that may unfold in the context of these changing landscapes. They need to be prepared for the potential implications that a hard Brexit has for those organizations based in the UK. So, depending on the political developments, it could become a very different ecosystem in respective countries. It is necessary to put in place some plans and strategies around that as opposed to reacting in an ad hoc way. I think there's just a lot of uncertainty. Factually, we don't know how these things will play out. There's a lot of checks and balances in the system, and a lot of these things that are spoken about may never become a reality or turn out to be not as bad as we think. Nevertheless, organizations need to be prepared for possible scenarios.

The era of the nationalism notion implies greater constraint at a time when organizations are more globally focused, because they've got to build their competitive advantage. So there are migrants, who move from one country to another, but the connection between the multinational and the employee is always in effect broken by nation states because of visa 
regulations, work permit requirements, etc. What does this mean for global talent management strategies? You operate on a global scale, so you have to have a global talent strategy, but if the resource, the talent resource, is becoming potentially less global, what does that mean for your strategy?

DC: I think the strategy needs to be differentiated more and recognize that there are centers of expertise in particular areas, and maybe that means that you need to relocate your centers of expertise to where the talents are or look at alternatives to traditional forms of employees. So if you look at some of the emerging work in that area, for instance the work of John Boudreau [Boudreau, 2015], who would argue that we need to move from a situation where we think about traditional employment and jobs towards thinking more in terms of pieces of work and what's required to do those pieces of work. Perhaps we need to rethink the boundaries of organizations and the notion of a traditional employee.

There's a lot of negative narrative around the gig economy, because when people think about the gig economy they think in the first place about the Uber driver or the Deliveroo person, but there's actually a high-end gig economy where individuals who are very experienced, who have very specialized skills, choose not to work for organizations anymore, because they want autonomy, they want meaningful work, and they want a work-life balance. Employment-related data suggest a trend towards increased numbers of freelancers, increased numbers of contractors, and increases of people in atypical employment. I think there's a certain core of people who have chosen non-traditional ways of employment as opposed to being forced into that situation. Our typical expectation of the gig economy worker is the one who has no choice, who has no other alternatives, but if you look at some of the work of Bidwell and Briscoe [Bidwell \& Briscoe, 
2009], for example, they found that people contract generally at two stages within their careers: first at the early stage, when they don't have the experience to get a long-term job contract, and second, when they have that experience but they want their autonomy and independence.

So I think a question for organizations looking forward is can they rethink the boundaries of the organization in terms of tapping into these skill sets regardless of location? There are certain types of sectors where that's less possible of course, if you work in defense or banking for example, because there are risk and compliance issues. Overall, I think we probably don't have enough understanding yet of how to manage those contractor-type relationships in a way that will really balance the access to the skills and the capabilities with the risk and compliance issues, regardless of industry but particularly in those industries. So there are some industries where it's more difficult, but for a lot of organizations it's very possible to tap into those different labor markets, and it doesn't really matter where those folks are. So I think that's certainly something that's growing in terms of a possible labor market.

\section{In terms of putting this global talent management strategy together, of course you have to think of cost and at the same time of skill. How can that balancing act be achieved?}

DC: I think that's become more difficult, because historically what organizations did was they looked abroad for cost-based advantages. So they set up IT service centers, for example in India, Bangalore, but the reality is that in India, even in China, those cost advantages are very quickly eroded. I think the landscape has changed so greatly that it's no longer possible to use those strategies to reduce your cost base. 
To me, in terms of talent, the key is to have an understanding in terms of technical capabilities. You need to ask yourself what the specific technical roles are that really differentiate your organization. In my experience a lot of CEOs, when they talk about talent and talent management, are talking about leadership succession, and the reality is that it's rarely the leaders in the organizations that differentiate the organizations. It's much more likely to be things like technical talent and the individuals who develop the products who really differentiate you in the marketplace. So for me a big part of that cost equation is an understanding of what the roles are that are really critical to your organization in terms of generating the greatest return. How to define that becomes visible once we increase the quality of people in those roles or if we increase the quantity of people in those roles. That's where the focus should be first and foremost, because that's what really makes a difference if you have really good talent. That's where you should disproportionately invest, because that's where you really get the most return.

As for the other roles, generally our experience is that good enough is good enough in many roles. So you need folks who can deliver in those roles, but you don't need the best capability in the world. Good enough is good enough. So that's where I can position my reward in the sixtieth percentile, for example which gives me better than average, which gives me people who'll do a great job, and that I don't have all these stars competing for limited resources. A lot of the criticism of a more exclusive approach to talent management is the assumption that the alternative to talent is not talented and that these stars are going to be treated really well and everyone else is treated poorly. There's lots of evidence that shows that you can treat people well and be very successful as an organization, even in very low-cost industries. Zeynep Ton [Ton, 2011] at MIT has done some great work in the field. She calls it the good-job strategy, that is, looking at low-margin, low-cost businesses that invest in their employees and outperform their 
competitors. Wayne Cascio [Cascio, 2006] showed very great examples of Walmart and Costco and how, in a low-margin business, if you treat people well, it adds significant value to your organization. This isn't about minimizing cost to the extent that people can't live; it's recognizing where to invest disproportionately and having a good baseline HR for everybody else.

So in terms of a talent strategy, to me the key is understanding where the differentiation happens, where the roles are that really add value to your organization. Once I understand those, that's where I need to target my investment, that's where I need the really high performers. For the rest of the roles, good enough is often good enough, which often makes it easier for me to fill those roles, because the bar isn't quite so high.

Let's put the focus on the key roles aside for a while and look at a broader talent approach, something that can be described as a key skills approach to talent management. What are your thoughts on tapping into the hidden talent of an organization? It's a different angle again from which to look at talent, by taking into account the diversity created by having a migrant population that potentially has different sets of skills to offer compared to local employees. I'm not talking about whether one has a degree in mathematics or not. I'm talking about the personal skills and softer skills that they can bring to the organization. So how do we tap into that, and is that a useful approach? Should we be thinking about talent in terms of key skills rather than key positions or key people?

DC: So, in a general sense I'm a little skeptical of the narrative around inclusive talent 
management, and in my experience, in those organizations that say everybody is talent, it can lead to a huge amount of frustration, because the reality is that most organizations need to draw the line somewhere. So we can have a situation, you know, where there are very conflicting messages coming to employees in which we say everyone's important, but the CEO comes to the plant and the five of you folks go to meet the CEO and I don't.

In my opinion your point is more fundamentally about skills. So in that context my question is: a talent for what? If I'm leading an organization, maybe you're a brilliant piano player but how does that add value to me? I think that for sure bringing individuals from different parts of the globe and different cultures together can stimulate innovation. Like there's some great work that looked at L'Oreal in Paris and how its product development teams work together [Hong \& Doz, 2013]. What happened was in Paris was that there were two different products, one that colored and one that lifted your skin. However, when individuals from India came and worked in Paris with the product development teams, they found that in developing markets people couldn't afford two products, so they made one product out of it. It became one of L'Oreal's best-selling products, but that innovation would have never happened if the insights from the developing market hadn't come to the product innovation center in Paris.

So I think that's a risk of borders becoming closed, that those innovations don't happen, rather than coming at it from the inclusive talent lens, for which I have yet to find an organization that really lives that. The professional service firms often say everyone's talent, but they have one of the most clinical operation systems that you can imagine for managing talent. So the average tenure in the big four is, I'd guess, two years. It's a classic up or out model. I'm less convinced by that narrative, but I think for sure the potential for innovation when we bring together individuals from around the organization is a great example of one of the benefits of 
talent flows. Equally important is when multinational organizations try to develop competencies at headquarters and an understanding of subsidiaries. The role of inpatriates or assignees from the subsidiaries to the headquarters as a learning mechanism, as linchpins, among others, is hugely significant. I think that's a far greater loss if we reduce talent flows than have more kinds of narrative around inclusiveness. I think it sounds great, but actually in my opinion it can make things more difficult, and the reality is simply that almost every organization does differentiate somewhere.

\section{Summary and outlook}

Since most industrialized economies rely on highly skilled as well as unskilled migrants to meet their labor shortages, it is hardly imaginable to roll back from globalization and further deepen nationalistic policies in the long run. Instead, the root cause of anti-globalization sentiments may be identified, and the deficits of globalization perhaps 'cured'. Similar to the resistance of the general public towards Japanese firms in the 1980s, globalization has again resulted in negative perceptions, and voters, especially the white working and middle classes, perceive globalization as a threat to their existence rather than an opportunity. Existential fears are widespread. These concerns are valid if people have limited knowledge or realistic understanding of the benefits and drawbacks of globalization. It is an important task for IHRM scholars and practitioners as well as politicians to reach out to understand such concerns, and focus on education that helps people understand and cope better with the changes that globalization brings.

The global talent management perspective focuses on a core group of highly skilled employees, those who add significant value to the firm in terms of their contribution to its differentiation from its competitors. If especially high-tech firms face political barriers in 
recruiting the best and brightest worldwide, they become a problem affecting competitiveness. However, multinational firms can take advantage of their global footprint and relocate certain functions and positions to "safe" regions that are unaffected by nationalistic policies. For instance, depending on whether the UK decides on a soft or a hard Brexit, in the case of the latter, we will be more likely to see firms located in the UK gradually moving certain operations to the larger European Union market.

Further, companies may rethink their organizational boundaries and the notion of the traditional employee. Today, many skilled workers no longer choose to work on a long-term contract for corporations, since they prefer autonomy, meaningful work, a work-life balance, and so on. Contrary to the current perception, the so-called "gig economy" does not consist solely of low-cost workers who are forced to jump from one short-term assignment to another. A significant number of highly skilled employees deliberately choose this kind of employment type, and companies would be well advised to respond to this trend by identifying the talent that they really need to differentiate themselves, and thus by hiring based on a particular ability instead of considering macroeconomic conditions or sticking to long-term succession plans. These trends can change the nature of the labor market and will lead to a different labor ecosystem in the future.

\section{Implications for future research}

Where does this leave the field of IHRM? Its current focus largely on multinational corporations and expatriate employees needs to broaden to incorporate other perspectives related to talent supply and demand on a global scale, including exploration of the inherent barriers as well as enablers of global mobility. Greater integration with other fields studying migration trends (such 
as human geography, including economic geography, migration studies, geopolitics, and population studies/demography) may, for example, allow the management-focused IHRM field to address the more complex talent management issues that organizations face on a daily basis.

Similarly, more ethnographic research may aid in uncovering the workplace experience of employees categorized as talent (including local and migrant individuals), or of the "nonemployees', working without contracts but who are nevertheless part of the economically-active labor force. As highlighted in the research by Mary Yoko Brannen (c.f. Brannen \& Lee, 2014; Brannen \& Thomas, 2010; Brannen, Moore, \& Mughan, 2013; Hanek, Lee, \& Brannen, 2014), biculturals (or multiculturals) as a source of rare talent may be particularly interesting to explore. These individuals offer different skill sets than that listed on a job description, but may add other types of value as part of a workforce.

In terms of the development of IHRM and the global talent management field to date, David Collings has similarly published extensively on this matter (c.f. Collings, 2014a, 2014b; Collings \& Mellahi, 2009; McDonnell, Collings, Mellahi, \& Schuler, 2017), highlighting the need for a more integrated approach to talent management within organizations, including linking global mobility and global talent management functions, as well as ensuring any talent strategy is fully aligned with the overall business strategy. Yet global talent management as an area of practice and of research will likely face new challenges going forward as organizational boundaries are molded by changes in the reality of national boundaries. Only time will tell where this will take people, organizations, and IHRM research.

\section{References}


Bidwell, M. J., \& Briscoe, F. (2009). Who contracts? Determinants of the decision to work as an independent contractor among information technology workers. Academy of Management Journal, 52(6), 1148-1168.

Bourdreau, J. (2015). We need to move beyond the employee vs. contractor debate. Harvard Business Review, July 8, 2015.

https://hbr.org/2015/07/we-need-to-move-beyond-the-employee-vs-contractor-debate

Burns, A. (2017). 2 federal judges rule against Trump's latest travel ban. New York Times, March 15, 2017. https://www.nytimes.com/2017/03/15/us/politics/trump-travel-ban.html

Brannen, M. Y., \& Lee, F. (2014). Bridging cultural divides: Traversing organizational and psychological perspectives on multiculturalism (pp. 417-437). In V. Benet-Martinez \& Y.-Y. Hong (Eds.), Oxford Handbook of Multicultural Identity. Oxford, UK: Oxford University Press.

Brannen, M. Y., Moore, F., \& Mughan, T. (2013, September). Strategic ethnography and reinvigorating Tesco Plc: Leveraging inside/out bicultural bridging in multicultural teams. Ethnographic Praxis in Industry Conference Proceedings, 1, 282-299.

Brannen, M. Y., \& Thomas, D. C. (2010). Bicultural individuals in organizations: Implications and opportunity. International Journal of Cross Cultural Management, 10(1), 5-16. 
Cascio, W. F. (2006). Decency means more than "always low prices": A comparison of Costco to Wal-Mart's Sam's club. Academy of Management Perspectives, 20(3), 26-37.

Collings, D. G. (2014a). Integrating global mobility and global talent management: Exploring the challenges and strategic opportunities. Journal of World Business, 49(2), 253-261.

Collings, D. G. (2014b). Toward mature talent management: Beyond shareholder value. Human Resource Development Quarterly, 25(3), 301-319.

Collings, D. G., \& Mellahi, K. (2009). Strategic talent management: A review and research agenda. Human Resource Management Review, 19(4), 304-313.

Cooke, F. L. (2014). Chinese multinational firms in Asia and Africa: Relationships with institutional actors and patterns of HRM practices. Human Resource Management, 53(6), 877896.

Dollar, D., \& Kraay, A. (2002). Growth is good for the poor. Journal of Economic Growth, 7(3), $195-225$.

Dustmann, C., Frattini, T., \& Halls, C. (2010). Assessing the fiscal costs and benefits of A8 migration to the UK. Fiscal Studies, 31(1), 1-41. 
Frith, B. (2016).What Brexit means for HR. HR Magazine, June 24, 2016.

http://www.hrmagazine.co.uk/article-details/what-brexit-means-for-hr

Hanek, K. J., Lee, F., \& Brannen, M. Y. (2014). Individual differences among global/multicultural individuals: Cultural experiences, identity, and adaptation. International Studies of Management \& Organization, 44(2), 75-89.

Hong, H. J., \& Doz, Y. (2013). L'Oreal masters multiculturalism. Harvard Business Review, 91(6), 114-118.

McDonnell, A., Collings, D. G., Mellahi, K., \& Schuler, R. (2017). Talent management: A systematic review and future prospects. European Journal of International Management, 11(1), $86-128$.

Osland, J. S. (2003). Broadening the debate: The pros and cons of globalization. Journal of Management Inquiry, 12(2), 137-154.

Peng, M. W., \& Shin, H. D. (2008). How do future business leaders view globalization? Thunderbird International Business Review, 50(3), 175-182.

Reuters. (2016). Brexit vote was for control over immigration, but we want good exit deal: UK's May. Reuters, October 19, 2016. http://www.reuters.com/article/us-britain-eu-mayidUSKCN12J1BG 
Streitfeld, D. (2017). Tech opposition to Trump propelled by employees, not executives. New York Times, February 6, 2017. https://www.nytimes.com/2017/02/06/business/trump-travel-banapple-google-facebook.html?_r=2

Ton, Z. (2011). Why "good jobs" are good for retailers. Harvard Business Review, 90(1-2), 12431.

\section{Biographical sketch}

Mary Yoko Brannen is the Jarislowsky East Asia (Japan) Chair at The Centre for Asia-Pacific Initiatives and Professor of International Business at the University of Victoria, Canada. She was recently inducted as Fellow of the Academy of International Business and was awarded an Honorary Doctorate at the Copenhagen Business School for her contributions to the field of cross-cultural management. Mary Yoko received her MBA with emphasis in International Business and $\mathrm{PhD}$ in Organizational Behavior with a minor in Cultural Anthropology from the University of Massachusetts at Amherst. Having taught at various Universities in the United States, Japan, China and France, Professor Brannen's consulting specialty is helping multinational firms realize their global strategic initiatives by aligning, integrating and deploying critical organizational resources. Her research has been published in influential outlets including the Academy of Management Journal, Academy of Management Review, California Management Review, Human Relations, International Journal of Cross Cultural Management, and the Journal of International Business Studies. Her most recent book, Language in 
International Business: Developing a Field with Terry Mughan will be available in November from Palgrave-Macmillan.

David Collings is Professor of Human Resource Management and co-director of the Leadership \& Talent Institute at Dublin City University (DCU), Ireland. Prior to joining DCU, he held faculty positions at the National University of Ireland, Galway and the University of Sheffield. He was also Visiting Professor at King's College London. He is Deputy Editor at the Journal of World Business, and former editor of the Human Resource Management Journal and the Irish Journal of Management. In 2014, 2015 and 2016 David was named by HR Magazine as one of the 'Most Influential International Thinkers' in the field of HRM. David has published widely in influential outlets and has edited seven books including the Oxford Handbook of Talent Management with Wayne Cascio and Kamel Mellahi and the Routledge Companion to International HRM with Paula Caligiuri and Geoff Wood. He sits on a dozen editorial boards including the Academy of Management Journal, Journal of Management and Journal of Management Studies.

Elaine Farndale is an Associate Professor in the School of Labor and Employment Relations at the Pennsylvania State University, where she is the Founder and Director of the Center for International Human Resource Studies. She is also affiliated to the Department of Human Resource Studies at Tilburg University in the Netherlands. Elaine's research includes: crossnational comparative human resource management (HRM); HRM in multinational corporations; global talent management; HRM and firm performance; the roles of the HR department; and HRM and employee engagement. She has published widely from her international collaborations 
in both the academic and practitioner press. Elaine completed her Ph.D. at Cranfield School of Management (UK), and worked previously as an HR specialist for several years.

Sven Horak is an Assistant Professor at The Peter J. Tobin College of Business, Department of Management at St. John's University in New York. In the field of international management his research interests include the analysis of informal social network structures, the influence of informal institutions on managerial decision making behavior and Asian Management. Sven has worked for several years in the East Asian automotive industry, managing operations for the Bosch Group in Tokyo, Seoul, and Stuttgart. Before joining Tobin, he was a post-doctoral fellow and research associate funded by the German Research Foundation (DFG) at the Institute of East Asian Studies (IN-EAST) and the Mercator School of Management at the Duisburg-Essen University in Germany. 